\title{
Nutrient limitation of periphyton growth in arctic lakes in south-west Greenland
}

\author{
E. J. Hogan · S. McGowan • N. J. Anderson
}

Received: 9 October 2013/Revised: 23 May 2014/Accepted: 28 May 2014/Published online: 14 June 2014

(C) The Author(s) 2014. This article is published with open access at Springerlink.com

\begin{abstract}
Many arctic lakes are oligotrophic systems where phototrophic growth is controlled by nutrient supply. Recent anthropogenic nutrient loading is associated with biological and/or physico-chemical change in several lakes across the arctic. Shifts in nutrient limitation (nitrogen $(\mathrm{N})$, phosphorus $(\mathrm{P})$, or $\mathrm{N}+\mathrm{P}$ ) and associated effects on the growth and composition of algal communities are commonly reported. The Kangerlussuaq region of south-west Greenland forms a major lake district which is considered to receive little direct anthropogenic disturbance. However, long-range transport of pollutant $\mathrm{N}$ is now reaching Greenland, and it was hypothesised that a precipitation gradient from the inland ice sheet margin to the coast might also deliver increased $\mathrm{N}$ deposition. In situ nutrient bioassays were deployed in three lakes across the region: ice sheet margin, inland (close to Kangerlussuaq) and the coast (near Sisimiut), to determine nutrient limitation of lakes and investigate any effects of nutrients on periphyton growth and community composition. Nutrient limitation differed amongst lakes: $\mathrm{N}$ limitation (ice sheet margin), $\mathrm{N}$ and $\mathrm{P}$ limitation (inland) and $\mathrm{N}+\mathrm{P}$ co-limitation (coast). Factors including variation in $\mathrm{N}$ supply, ice phenology, seasonal algal succession, community structure and
\end{abstract}

E. J. Hogan $(\bowtie) \cdot$ N. J. Anderson

Department of Geography, Loughborough University,

Loughborough, UK

e-mail: E.J.Hogan@lboro.ac.uk

S. McGowan

School of Geography, University of Nottingham, University

Park, Nottingham, UK

S. McGowan

School of Geography, University of Nottingham Malaysia Campus, Jalan Broga, 43500 Semenyih, Selangor Darul Ehsan, Malaysia physical limnology are explored as mechanisms to explain differences amongst lakes. Nutrient limitation of arctic lakes and associated ecological impacts are highly variable, even across small geographic areas. In this highly sensitive region, future environmental change scenarios carry a strong risk of significantly altering nutrient limitation; in turn, potentially severely impacting lake structure and function.

Keywords Algae $\cdot$ Arctic $\cdot$ Nitrogen $\cdot$ Nutrient limitation $\cdot$ Periphyton $\cdot$ Phosphorus

\section{Introduction}

Arctic lakes are traditionally classified as low-resource, ultraoligotrophic systems in which phototrophic growth is tightly controlled by nutrient availability (Bonilla et al. 2005). However, many arctic lakes have recently experienced anthropogenically enhanced nutrient loading from sources including warming-induced melt of permafrost and increased terrestrial run-off as well as increased atmospheric nitrogen $(\mathrm{N})$ deposition (Wolfe et al. 2006; Anisimov et al., 2007; Holtgrieve et al. 2011). As a result of increased nutrient supply, many oligotrophic lakes have undergone or are currently experiencing significant biological, chemical and physical change (Smol et al. 2005; Bergström and Jansson 2006; Wolfe et al. 2006; Holtgrieve et al. 2011). In response to such change, several studies have recently focussed attention on nutrient limitation in high-latitude lakes in order to determine which essential macro-nutrient $(\mathrm{N}$, phosphorus $(\mathrm{P})$ or a combination of $\mathrm{N}+\mathrm{P}$ ) exerts the greatest control over phototrophic growth and how this might change in response to variation in nutrient supply (e.g. Levine and Whalen 2001; 
Bergström et al. 2005; Elser et al. 2009a, 2009b; Symons et al. 2012). A common feature of many of these studies is a focus on nutrient limitation of phytoplankton growing in the open water column (Levine and Whalen 2001; Bergström and Jansson 2006, 2008; Elser et al. 2009a, b). This is despite evidence which suggests that phytobenthos (periphyton) communities can achieve very high standing stocks (Bonilla et al. 2005) and often dominate total lake biomass and/or production in high-latitude lakes (Vadeboncoeur et al. 2003; Hodgson et al. 2004; Bonilla et al. 2005). The contribution of phytobenthos and phytoplankton communities towards total lake production is also highly variable and has been shown to shift in response to physico-chemical gradients, including nutrient availability (Vadeboncoeur et al. 2003). For example, in response to increasing $\mathrm{P}$ availability (2-430 $\mu \mathrm{g}^{-1}$ ) Vadeboncoeur et al. (2003) reported a marked community shift from benthic- to planktonic-dominated productivity in multiple lakes across the globe (including arctic sites).

The success of periphyton communities in arctic lakes is attributed to their growth on the lake bottom, where the physical environment is more stable than the open water and where there is a source of nutrients via sedimentation of particles from the water above, as well as from underlying lake sediments (Hansson 1992; Vincent et al. 2008). This close proximity to a nutrient source has been frequently mistaken as evidence that periphyton growth is not nutrient limited and is controlled by other factors (e.g. light, temperature, grazing) (Hansson 1992; Vinebrooke and Leavitt 1996). This has resulted in fewer studies investigating the degree and type of nutrient limitation experienced by algae in this habitat. However, periphyton communities in arctic lakes commonly contain species with growth-led demand for nutrients which can be as high as that of phytoplankton (Bonilla et al. 2005), and there is growing evidence that periphyton respond rapidly to $\mathrm{N}$ and/or P supply in oligotrophic lakes (Vinebrooke and Leavitt 1998; Elser et al. 2007; Lepori and Robin 2014).

A common method employed to determine nutrient limitation is nutrient enrichment bioassays (Elser et al. 1990; Levine and Whalen 2001; Symons et al. 2012). In such experiments, algal growth is measured in response to artificially manipulated nutrient concentrations. This approach (including both laboratory and in situ experiments) provides a useful biomonitoring tool to assess the biological availability of nutrients and help infer any nutrient limitation of algal growth within a particular lake (Symons et al. 2012). Nutrient bioassays are especially valuable in remote arctic lakes where reliable, accurate measurements of very low nutrient concentrations can be challenging and where nutrient availability can vary markedly both spatially across different lake habitats and temporally over the course of a growing season. In addition, although they provide information on the nutrient status of lake water, variation in the specific design of nutrient bioassays can help to provide a reliable indication of the nutrient limitation of a particular algal community (e.g. phytobenthos or phytoplankton).

The Kangerlussuaq region of south-west (SW) Greenland is typical of much of the Arctic in terms of its climate, vegetation and lake density (Nielsen 2010). Direct anthropogenic disturbance of lakes is considered to be low. However, the region experiences a precipitation gradient which increases from the inland ice sheet margin to the coast $c .150 \mathrm{~km}$ away (Anderson et al. 2012) and has been linked to increased atmospheric transport and deposition of pollutants including mercury and lead (Bindler et al. 2001a, 2001b). We hypothesised that the precipitation gradient might also deliver increased $\mathrm{N}$ deposition as there is growing evidence of long-range transport of $\mathrm{N}$ to sites far removed from pollution sources, including Greenland (Hastings et al. 2009). Arens et al. (2008) suggested $<1 \mathrm{~kg} \mathrm{~N} \mathrm{ha}^{-1}$ year $^{-1}$ deposition to high arctic dwarf shrub tundra in north-west Greenland and preliminary measurements at Kangerlussuaq report $c .0 .2 \mathrm{~kg} \mathrm{~N} \mathrm{ha}^{-1}$ year $^{-1}$ (Anderson, unpub.). The current study was designed as a preliminary investigation to determine nutrient limitation of arctic lakes in SW Greenland and to investigate any effects of $\mathrm{N}, \mathrm{P}$ and $\mathrm{N}+\mathrm{P}$ supply on periphyton growth and community structure.

\section{Materials and methods}

\section{Study area}

The Kangerlussuaq region between $66.5-67.2^{\circ} \mathrm{N}$ and $50-53.5^{\circ} \mathrm{W}$ forms part of the widest ice-free margin of SW Greenland (Fig. 1). There are $>15,000$ lakes across the area (Anderson and Stedmon 2007), most of which are oligotrophic and chemically dilute (Anderson et al. 2001). Mean annual precipitation increases from $<150 \mathrm{~mm} \mathrm{year}^{-1}$ at the ice sheet margin to $\geq 500 \mathrm{~mm} \mathrm{year}^{-1}$ at the coast (Anderson et al. 2009), with the greatest percentage of this received as snowfall during winter. The climate at the ice sheet margin and inland at Kangerlussuaq is continental low arctic compared with moist, oceanic low arctic at the coast. Summer temperatures close to the ice sheet margin typically remain $<10{ }^{\circ} \mathrm{C}$ as a result of katabatic winds which blow off the ice sheet, whilst coastal fog banks and sea breezes reduce June-August temperatures at the coast. Higher summer temperatures at Kangerlussuaq increase evaporative forcing of the inland lakes, accounting for high conductivity values (Table 1). 


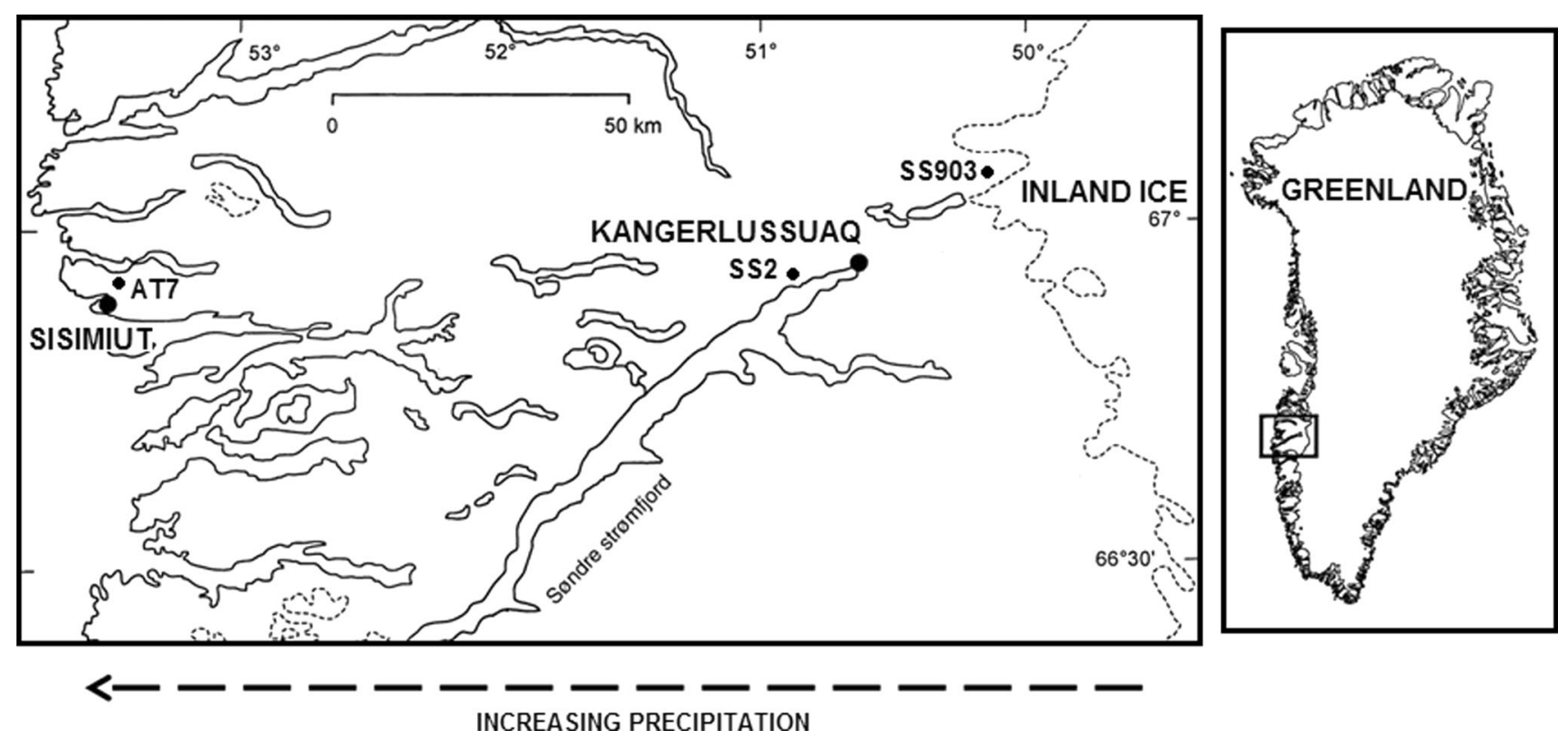

Fig. 1 Map of study region in south-west Greenland showing location of study lakes

Table 1 Physical parameters and water chemistry of study lakes

\begin{tabular}{|c|c|c|c|}
\hline Location & $\begin{array}{l}\text { Ice sheet } \\
\text { margin }\end{array}$ & Inland & Coast \\
\hline Lake & SS903 & SS2 & AT7 \\
\hline Latitude $\left({ }^{\circ} \mathrm{N}\right)$ & 66.073 & 66.997 & 66.582 \\
\hline Longitude $\left({ }^{\circ} \mathrm{W}\right)$ & 50.101 & 50.970 & 53.350 \\
\hline Lake area (ha) & 38 & 36.8 & 6.5 \\
\hline Maximum depth (m) & 30 & 11.2 & 20 \\
\hline Altitude (m asl) & 350 & 185 & 450 \\
\hline Mean July air temperature $\left({ }^{\circ} \mathrm{C}\right)^{\mathrm{a}}$ & 9 & 12.5 & 9.1 \\
\hline July precipitation $\left(\mathrm{mm} \mathrm{year}^{-1}\right)^{\mathrm{a}}$ & 17 & 16 & $27^{\mathrm{b}}$ \\
\hline Date NSD deployed & 30.06 .11 & 29.06 .11 & 02.07 .11 \\
\hline Date NSD harvested & 11.08 .11 & 09.08 .11 & 06.08 .11 \\
\hline $\mathrm{TP}\left(\mu \mathrm{g}^{-1}\right)$ & 2.21 & BDL & BDL \\
\hline $\operatorname{SRP}\left(\mu \mathrm{g}^{-1}\right)$ & 2.03 & 1.40 & 0.49 \\
\hline $\mathrm{NO}_{3}^{-}\left(\mu \mathrm{g} \mathrm{l}^{-1}\right)$ & BDL & BDL & 13.4 \\
\hline $\mathrm{NH}_{4}^{+}\left(\mu \mathrm{g} \mathrm{l}^{-1}\right)$ & 1.56 & 2.34 & BDL \\
\hline $\mathrm{TN}\left(\mu \mathrm{g}^{-1}\right)$ & 380 & 721 & 33 \\
\hline Alkalinity $\left(\mu \mathrm{eq} 1^{-1}\right)$ & 2,300 & 1,400 & 100 \\
\hline $\mathrm{pH}$ & 8.03 & 8.2 & 6.5 \\
\hline Water temperature $\left({ }^{\circ} \mathrm{C}\right)$ & 11.81 & 14.47 & 4.55 \\
\hline Conductivity $\left(\mu \mathrm{S} \mathrm{cm}^{-1}\right)$ & 174 & 332 & 39 \\
\hline $\mathrm{DO}\left(\mathrm{mg} \mathrm{l}^{-1}\right)$ & 10.66 & 10.95 & 12.37 \\
\hline $\begin{array}{l}\text { Light attenuation coefficient } \\
\left(K_{\mathrm{d}}, \mathrm{m}^{-1}\right)\end{array}$ & 0.23 & 0.66 & 0.2 \\
\hline Depth at $10 \%$ irradiance $(\mathrm{m})$ & 9 & 5 & N/A \\
\hline Depth at $1 \%$ irradiance $(m)$ & 19 & 7 & $17^{\mathrm{c}}$ \\
\hline
\end{tabular}

Values from July $2011^{\mathrm{a}}$ or $2010^{\mathrm{b}}$ from www.dmi.dk or www.promise. $\mathrm{dk},{ }^{\mathrm{c}}$ Estimated from Secchi disc (SD) reading taken 2010 and equation $1 \%$ irradiance $=2(\mathrm{SD})$. BDL below detection limits, N/A not available
Study lakes

Three study lakes were selected as representative systems for three distinct locations differing in climate and precipitation across the region: ice sheet margin (SS903), inland close to Kangerlussuaq (SS2) and at the coast near Sisimiut (AT7) (Fig. 1). The study lakes are all small ( $<40 \mathrm{ha})$, glacially scoured basins, which are typically frozen from mid-September to mid-June, although the period of ice cover is extended by several weeks at the coast (Anderson and Brodersen 2001). Phytoplankton chlorophyll $a$ values $\left(\mathrm{Chl} a,<0.5 \mu \mathrm{g} \mathrm{l}^{-1}\right)$ place lakes in the ultraoligotrophic to oligotrophic range (Villeneuve et al. 2001). There are regional differences in the physical properties of lakes including temperature, stratification depth, chemical composition and light availability (Table 1 ).

Nutrient diffusing substrata

Nutrient diffusing substrata (NDS) were used to measure nutrient limitation following the general method of Matlock et al. (1998). The NDS were constructed with acid washed 250-ml Nalgene bottles filled with one of the four solutions made up with nutrient salts and deionised water: control (no nutrients added), $\mathrm{N}\left(90 \mu \mathrm{M} \mathrm{NH}_{4} \mathrm{NO}_{3}\right), \mathrm{P}(6 \mu \mathrm{M}$ $\mathrm{NaH}_{2} \mathrm{PO}_{4}$ ) and $\mathrm{N}+\mathrm{P}$ (concentrations as previously stated). We selected $\mathrm{NH}_{4} \mathrm{NO}_{3}$ to provide both reduced and oxidised forms of $\mathrm{N}$, based on evidence from previous investigations which reported no significant difference in the release rate of $\mathrm{NO}_{3}{ }^{-}$and $\mathrm{NH}_{4}{ }^{+}$from NDS (Fairchild et al. 1989). A sodium salt was selected as the carrier for 

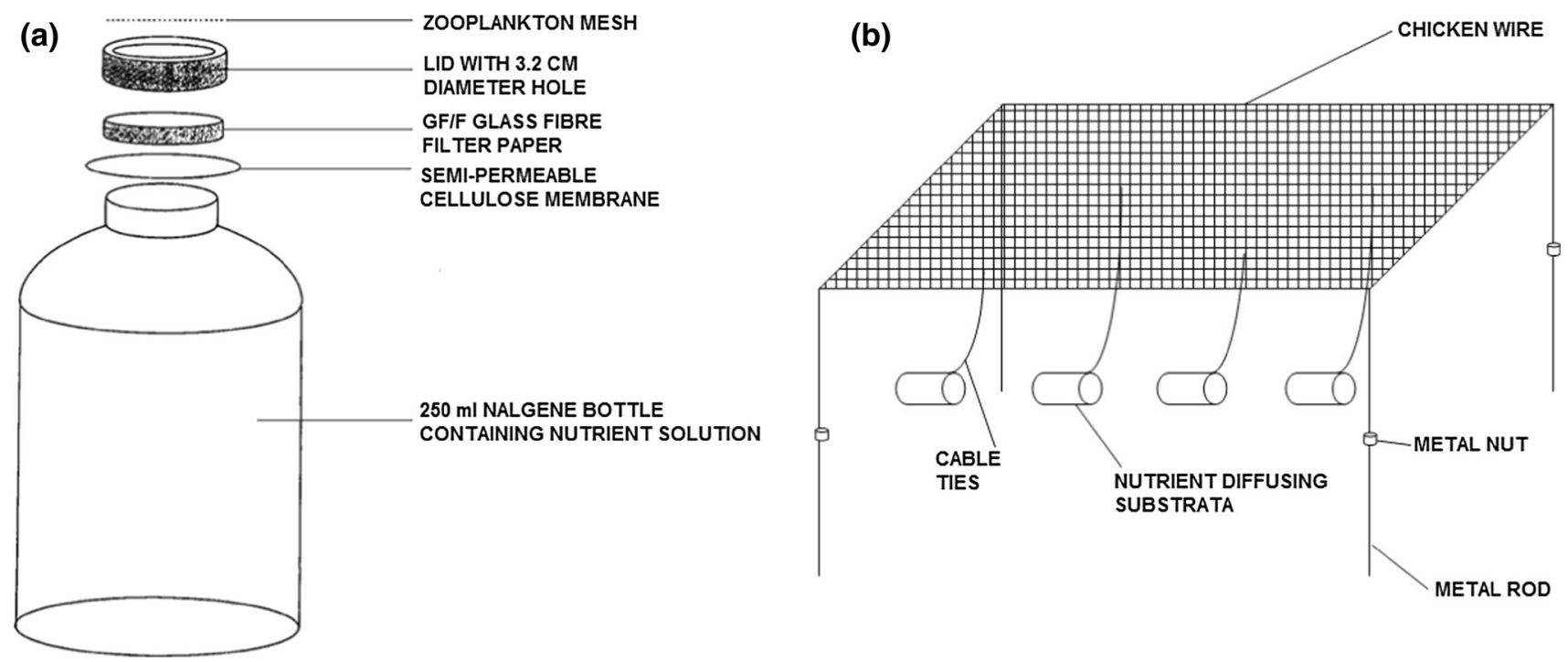

Fig. 2 Diagram of a components of individual nutrient diffusing substrata (NDS) and $\mathbf{b}$ experimental set-up with NDS attached to a metal frame

$\mathrm{PO}_{4}{ }^{3-}$ because it provides the most biologically available form of $\mathrm{P}$ without interference from other nutrients (Matlock et al. 1998). The concentrations were selected as $c$. $1,500 \times$ and $c .100 \times$ current $\mathrm{N}$ and $\mathrm{P}$ concentrations, respectively, in ice sheet margin lakes. These values were chosen to permit continual diffusion of nutrients to the growth substratum over the duration of the investigation and encourage periphyton colonisation.

A square of hydrated semi-permeable $14 \mathrm{kDa}$ dialysis membrane tubing (Spectra/Por $25 \mathrm{~mm}$ flat width tubing, 12-14 kDa, Fisher Scientific, Loughborough, UK) was cut and carefully placed over the neck of the bottle, providing a biofilter preventing bacterial and algal contamination of the nutrient solution. A $0.7-\mu \mathrm{m} \mathrm{GF} / \mathrm{F}$ glass fibre filter paper (47 mm diameter, Whatman, UK) was laid over the semipermeable membrane (rough-side up) providing a substrate onto which periphyton could attach and grow and which could be easily removed for analysis at the end of the experiment (Fig. 2a). The lid of the Nalgene bottle was modified with a 32-mm-diameter hole, and this was carefully screwed onto the bottle, taking care not to rip the filter paper or semi-permeable membrane. Grazing pressure by zooplankton was reduced by covering the opening of the NDS with a square of 150- $\mu$ m zooplankton mesh (Fig. 2a).

Nutrient diffusing substrata were deployed for 35-40 days during June-August 2011 (Table 1). Six replicates from each treatment were randomly attached to the underside of a wire frame, orientated perpendicular to the lake bottom in line with Matlock et al. (1998) (Fig. 2b). The frame was placed in a macrophyte-free region in the littoral zone at a depth of $0.75 \mathrm{~m}$, ensuring NDS were completely submerged, positioned at a depth of $c .0 .07 \mathrm{~m}$ above the bottom of the lake.
Upon collection, NDS were removed from study lakes and $\mathrm{GF} / \mathrm{F}$ filter papers were recovered, immediately wrapped in aluminium foil and stored at $-18{ }^{\circ} \mathrm{C}$ prior to high-performance liquid chromatography (HPLC) pigment analysis. Recovery of GF/F filter papers was high, with the loss of six samples.

Matlock et al. (1998) reported diffusion rates of $17 \pm 16 \mu \mathrm{g} \mathrm{cm}^{-2} \mathrm{~h}^{-1}$ and $27 \pm 17 \mu \mathrm{g} \mathrm{cm}^{-2} \mathrm{~h}^{-1}$ for $1.5 \mathrm{mM} \mathrm{PO}_{4}{ }^{3-}$ and $8.1 \mathrm{mM} \mathrm{NO}_{3}{ }^{-}$, respectively, across the same NDS at $26{ }^{\circ} \mathrm{C}$. The authors suggested that the rate of diffusion for both ions was approximately linear and calculated that the concentration of ions within NDS decreased by $c .15 \%$ over 14 days and by $25 \%$ over 21 days (Matlock et al. 1998). Based on these rates of diffusion and given the nutrient concentrations supplied in the current study, it was estimated that under lower temperatures and limited water flow, nutrient concentrations in NDS should not become depleted and nutrient release to the growing surface would continue over the duration of the investigation.

Photosynthetically active radiation and water chemistry

Photosynthetically active radiation (PAR), nutrient concentrations (soluble reactive phosphorus (SRP), total phosphorus (TP), nitrate $\left(\mathrm{NO}_{3}{ }^{-}\right)$, ammonium $\left(\mathrm{NH}_{4}{ }^{+}\right)$and total nitrogen $(\mathrm{TN})$ ) and physical properties (temperature, $\mathrm{pH}$, conductivity and dissolved oxygen (DO) concentration) were measured on the date NDS were deployed (Table 1). Lakes SS903 and SS2 were sampled throughout the water column at the deepest part (Table 1). However, AT7 was sampled from the ice-free littoral moat as residual ice cover prevented safe access to the deepest point in the centre of the lake. Photosynthetically active radiation was 
measured with a Li-cor LI-192SA underwater quantum sensor attached to a LI-1400 data logger (LI-COR Biosciences, Lincoln, NE, USA) at SS903 and SS2, whilst a Secchi disc reading was taken at AT7 on 5 August 2010. To compensate for different weather conditions, all PAR readings were normalised against the surface reading $(100 \%)$. The percentage of PAR at all depths was $\ln$ transformed and plotted against depth, with the gradient of this relationship used to estimate light attenuation through the water column (extinction coefficient, $K_{\mathrm{d}}, \mathrm{m}^{-1}$ ) (Table 1). For AT7, the Secchi disc reading was transformed to give an approximate $K_{\mathrm{d}}$ value using the equation: $K_{\mathrm{d}}=1.7 / \mathrm{SD}$ (Poole and Atkins 1929; Table 1). Conductivity, $\mathrm{pH}$, temperature and $\mathrm{DO}$ were measured using a YSI datasonde probe (YSI Incorporated, Yellow Springs, Ohio, USA) at a depth of $2 \mathrm{~m}$ at the deepest point of SS903 and SS2 and at a depth of $1 \mathrm{~m}$ in the littoral moat at Lake AT7. Water samples for chemical analysis were also taken from these locations and depths. Samples for the analysis of SRP, $\mathrm{NO}_{3}{ }^{-}$and $\mathrm{NH}_{4}{ }^{+}$were filtered through $0.7-\mu \mathrm{m} \mathrm{GF} / \mathrm{F}$ glass fibre filter papers in the field with unfiltered water collected for TP and TN analysis. Samples for water chemistry were kept cold, in the dark, in the field until they were returned to the laboratory (typically within $8 \mathrm{~h}$ ) where they were stored at $4{ }^{\circ} \mathrm{C}$ in the dark until analysis. Soluble reactive phosphorus, $\mathrm{TP}, \mathrm{NH}_{4}{ }^{+}$and $\mathrm{NO}_{3}{ }^{-}$were analysed by standard colourimetric methods following Mackereth et al. (1989), whilst TN was measured by alkaline potassium persulphate digestion and UV absorption (J. Saros, University of Maine, USA). Due to logistical constraints associated with working in remote environments, water chemistry was analysed as soon as possible after sample collection (typically within 4 days). We note that a delay in analysis of water chemistry can permit changes in major nutrient concentrations via algal and microbial activity. However, in the current investigation, any such changes are not deemed to alter major conclusions drawn.

Periphyton photosynthetic pigment analysis including chlorophyll $a$

Photosynthetic pigments were measured with standard highperformance liquid chromatography (HPLC) following Leavitt \& Hodgson (2001) and described in McGowan et al. (2012). Characterisation of different algal communities was based on HPLC separations of chlorophylls and carotenoids from all algal groups (Chl a), chlorophytes (chlorophyll $b$ (Chl $b$ ), lutein and violaxanthin), cryptophytes (alloxanthin), cyanobacteria (canthaxanthin and zeaxanthin), dinoflagellates (peridinin) and siliceous algae including diatoms and chrysophytes (fucoxanthin). Total pigment concentration was calculated from the sum of the above pigments (excluding $\mathrm{Chl} a$ ) in addition to concentrations of diadinoxanthin, diatoxanthin, pheophytin $b$, pheophytin $a$ and $\beta$-carotene, which are not discussed in further detail in the current study. Chlorophyll $a$ and pigment concentrations are calculated from the total area over which nutrients could diffuse and periphyton attach $\left(8.04 \mathrm{~cm}^{2}\right)$. Whilst photosynthetic pigment biomarkers provide coarser taxonomic information than microscopic algal counts, the design of this investigation did not permit microscopic examination of algal material from recovered NDS and the taxonomic resolution provided was considered sufficient to address our research hypotheses and for a preliminary investigation.

Statistical analysis

SPSS ((UK) Ltd, Woking, UK) was used to perform standard statistical analyses. All data were $\log _{10}$ transformed and checked for normality and homoscedasticity. For each lake, one-way ANOVA with Least Squares Difference post hoc tests was used to determine differences in $\mathrm{Chl} a$ and pigments between nutrient treatments. Nutrient limitation was determined following the hierarchical logic sequence presented in Maberly et al. (2002) with $P<0.05$ as statistically significant. Nitrogen limitation was ascribed when measured values were significantly greater in $\mathrm{N}$-treated samples compared against controls. Co-limitation was inferred when $\mathrm{N}+\mathrm{P}$ was the only treatment resulting in significantly greater values than control samples (i.e. neither $\mathrm{N}$ nor $\mathrm{P}$ addition alone stimulated biomass yield significantly). Where $\mathrm{N}$ and $\mathrm{P}$ supplied alone stimulated periphyton biomass significantly, both nutrients were determined to limit growth.

\section{Results}

Physical parameters

Concentrations of SRP ranged from $0.5 \mu \mathrm{g}^{-1}$ in AT7 to $2.0 \mu \mathrm{g} \mathrm{l}^{-1}$ in SS903 (Table 1). Concentrations of $\mathrm{NH}_{4}^{+}$ were low $\left(<2.3 \mu \mathrm{g} \mathrm{l}^{-1}\right)$ and below detection limits in AT7 (Table 1). In contrast, $\mathrm{NO}_{3}{ }^{-}$was only detected in AT7 $\left(13.4 \mu \mathrm{g} \mathrm{l}^{-1}\right)$. Maximum TN was measured at SS2, where it was approximately twice the concentration recorded in SS903 and $95 \%$ greater than in AT7.

Surface water temperature ranged from 4.6 to $14.5^{\circ} \mathrm{C}$ across all three lakes (Table 1). The pH of SS2 and SS903 was similar (8.2 and 8.03, respectively), but a much lower $\mathrm{pH}$ of 6.5 was recorded at AT7 (Table 1). Alkalinity ranged between 100 and 2,300 $\mu \mathrm{eq} 1^{-1}$, and conductivity was recorded between 39 and $322 \mu \mathrm{S} \mathrm{cm}^{-1}$ (Table 1). Similar values were calculated for the light extinction coefficient $\left(K_{\mathrm{d}}\right)$ in $\operatorname{SS} 903\left(0.23 \mathrm{~m}^{-1}\right)$ and $\operatorname{AT7}\left(0.2 \mathrm{~m}^{-1}\right)$, but was higher at SS2 $\left(0.66 \mathrm{~m}^{-1}\right)$. 

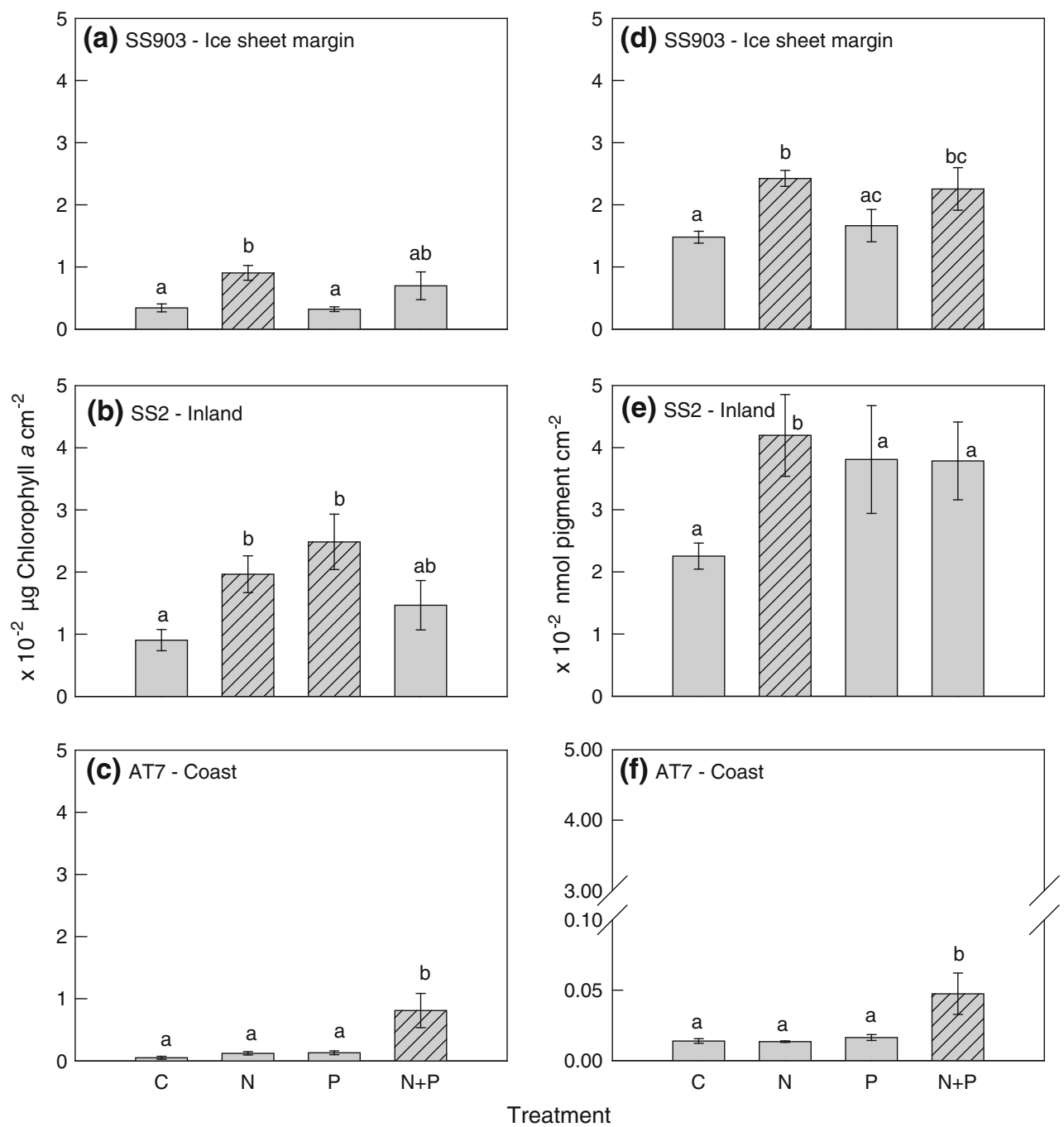

Fig. 3 Effect of nutrient supply (nitrogen $(\mathrm{N})$, phosphorus $(\mathrm{P})$ and $\mathrm{N}+\mathrm{P}$ ) on periphyton chlorophyll $a$ concentration $(\mathbf{a}-\mathbf{c})$ and total pigment biomass (d-f) compared against control samples (no nutrients) in three study lakes from south-west Greenland: ice sheet margin (SS903, a, d), inland close to Kangerlussuaq (SS2, b, e) and at the coast near Sisimiut (AT7, c, f). Plotted values are means $(n=4-6) \pm 1$ SEM, with one-way ANOVA and LSD post hoc test

used to calculate significant differences between nutrient treatments for each lake. Points assigned the same letter are not significantly different at the $P \leq 0.05$ level, with results statistically significant from control samples highlighted by shaded bars. Note the break in the $y$-axis scale between 0.1 and $3\left(\times 10^{-2} \mathrm{nmol}\right.$ pigment $\left.\mathrm{cm}^{-2}\right)$ in plot $\mathbf{f}$

\section{Periphyton chlorophyll $a$}

\section{Periphyton photosynthetic pigments}

Nutrient enrichment significantly increased $\mathrm{Chl} a$ in all three study lakes $(P<0.025$, Fig. 3a-c). Nitrogen addition significantly increased Chl $a$ by $164 \%$ relative to control samples in SS903 $(P=0.003$, Fig. 3a). At SS2, both N and $\mathrm{P}$ addition alone resulted in significant increases $(P<0.006)$ in Chl $a$ to $2 \times 10^{-2} \pm 0.3 \times 10^{-2} \mu \mathrm{g} \mathrm{cm}{ }^{-2}$ $(+\mathrm{N})$ and $2 \times 10^{-2} \pm 0.6 \times 10^{-2} \mu \mathrm{g} \mathrm{cm}^{-2}(+\mathrm{P})$ compared against control samples $\left(0.7 \times 10^{-2} \pm 0.2 \times 10^{-2}\right.$ $\mu \mathrm{g} \mathrm{cm}{ }^{-2}$, Fig. 3b). At AT7, N + P significantly increased Chl $a(P=0.007)$ by $7-16 \times$ compared against all other nutrient treatments in this lake (Fig. 3c).

Addition of $\mathrm{N}$ significantly increased total photosynthetic pigment concentration in SS903 and SS2 $(P<0.023$, Fig. 3d, e), whilst supply of $\mathrm{N}+\mathrm{P}$ together resulted in a significant increase in total pigment concentration in AT7 $(P=0.008$, Fig. 3f). The lowest pigment concentrations $\left(<8 \times 10^{-3} \mathrm{nmol} \mathrm{cm}^{-2}\right)$ were recorded in AT7, and commonly, individual pigments were below detection limits in this lake (Fig. 4). In SS903, fucoxanthin and lutein-zeaxanthin (indicating siliceous and green algae) accounted for up to 16 and $10 \%$ of total pigment concentration, respectively (Fig. 4d, m). In addition, $\mathrm{N}$ supply significantly 
increased fucoxanthin (siliceous algae), violaxanthin, lutein-zeaxanthin and $\mathrm{Chl} b$ (green and blue-green algae) by a factor of $2.7-12$ relative to control samples $(P<0.01$, Fig. $4 \mathrm{~d}, \mathrm{~g}, \mathrm{~m}, \mathrm{~s})$ and resulted in the highest concentration of alloxanthin (suggesting an increase in cryptophytes). There was little effect of $\mathrm{P}$ enrichment on pigment concentrations in SS903. Peridinin (indicating dinoflagellates) was only detected in the $\mathrm{N}+\mathrm{P}$ treatment, and the supply of $\mathrm{N}+\mathrm{P}$ significantly increased indicators of siliceous and green algae, including fucoxanthin, violaxanthin, lutein-zeaxanthin and $\mathrm{Chl} b$ compared to control samples (Fig. 4d, g, m, s). However, individual pigment concentrations recorded under N + P treatments in SS903 were lower than those achieved with $\mathrm{N}$ addition alone.

Nitrogen significantly increased siliceous and green algal pigments fucoxanthin and violaxanthin in SS2 $(P<0.038$, Fig. 4e, h). Alloxanthin, lutein-zeaxanthin and $\mathrm{Chl} b$ also increased in response to $\mathrm{N}$ supply when compared against control samples (Fig. 4k, n, t). Phosphorus stimulated fucoxanthin, violaxanthin and alloxanthin by 58-90 \% compared to control samples (Fig. 4e, h, k) and resulted in the maximum peridinin (dinoflagellates) recorded in SS2. The addition of $\mathrm{P}$ also increased canthaxanthin (cyanobacteria) by a factor of $c .13$ relative to concentrations measured in control samples (Fig. 4q). The supply of $\mathrm{N}+\mathrm{P}$ increased pigment concentrations of siliceous, green algae and cyanobacteria (fucoxanthin, violaxanthin, lutein-zeaxanthin and $\mathrm{Chl} b$ ) by $c$. 40-200\% compared to control samples (Fig. 4e, h, n, t) with fucoxanthin (siliceous algae) accounting for the largest proportion of total periphyton pigment concentration (15-27\%) across all nutrient treatments in SS2 (Fig. 4e).

Periphyton pigments were reduced in AT7 compared against other study lakes (Fig. 4). Fucoxanthin and luteinzeaxanthin were the only detectable pigments in control samples, and fucoxanthin and violaxanthin (siliceous and green algae) were the only pigments recorded on $\mathrm{N}$-treated samples (Fig. 4f, i). Phosphorus supply increased fucoxanthin concentration (Fig. 4f) and resulted in detection of Chl $b$ (Fig. $4 \mathrm{u}$ ). Dual nutrient enrichment significantly increased fucoxanthin and lutein-zeaxanthin by a factor of $c .17$ and c. 70 , respectively $(P<0.05$, Fig $4 \mathrm{f}$, o), relative to control samples. The highest measured concentration of $\mathrm{Chl} b$ in AT7 reached $3 \times 10^{-3} \pm 1 \times 10^{-3} \mathrm{nmol} \mathrm{cm}^{-2}$ in response to the supply of $\mathrm{N}+\mathrm{P}($ Fig. $4 \mathrm{u})$. Peridinin (dinoflagellates), alloxanthin (cryptophytes) and canthaxanthin (cyanobacteria) were not detected at this lake (Fig. 4c, 1, r).

\section{Discussion}

Periphyton growth in oligotrophic lakes in SW Greenland is constrained by nutrient availability. The addition of $\mathrm{N}, \mathrm{P}$ or $\mathrm{N}+\mathrm{P}$ increased Chl $a$ by a factor of $1.5-16$ in all three study lakes, suggesting a severe shortage of bioavailable nutrients for growth. This is consistent with studies which report $\mathrm{N}$ and/or $\mathrm{P}$ limitation in polar, alpine and montane oligotrophic lakes (e.g. Levine and Whalen 2001; Symons et al. 2012), including SW Greenland (Brutemark et al. 2006), as well as for community-specific periphyton responses (Blumenshine et al. 1997; Vadeboncoeur et al. 2001; Elser et al. 2007; Lepori and Robin 2014).

Nutrient limitation varied amongst study lakes. Nitrogen limitation was observed at SS903 (ice sheet margin), whilst evidence of both $\mathrm{N}$ and $\mathrm{P}$ limitation was recorded at SS2 (inland) and $\mathrm{N}+\mathrm{P}$ co-nutrient limitation was determined for AT7 (coast). At SS903 and SS2, addition of N significantly increased periphyton $\mathrm{Chl} a$ and pigments indicative of siliceous algae and chlorophytes. Lepori and Robin (2014) reported that green algae (including filamentous forms) grew more favourably in response to the supply of $\mathrm{N}$ from NDS in oligotrophic alpine lakes. Nydick et al. (2004) also recorded an increase in chlorophytes in response to $\mathrm{N}$ enrichment in shallow mountain lakes of the Snowy Range, Wyoming, USA, which the authors attributed to a high optimum $\mathrm{N}$ requirement of these taxa. Siliceous algae can also be highly competitive for inorganic $\mathrm{N}$ uptake in oligotrophic systems (Tilman et al. 1986; Lomas and Glibert 1999). At SS903, the action of strong katabatic winds in the littoral zone might aid $\mathrm{P}$ release from sediments, altering lake water $\mathrm{N}: \mathrm{P}$ stoichiometry and enhancing periphyton growth-led demand for $\mathrm{N}$.

At SS2, P addition also significantly increased $\mathrm{Chl} a$ and total pigment concentration, although different taxa responded compared with $\mathrm{N}$ addition. Canthaxanthin increased by $c .90 \%$ in P-treated samples compared to control treatments, suggesting a marked increase in cyanobacteria. Many cyanobacteria are able to fix atmospheric $\mathrm{N}_{2}$, thereby possessing a mechanism to alleviate $\mathrm{N}$ limitation. However, $\mathrm{N}_{2}$-fixation is an energy intensive process (Sprent and Sprent 1990; Postgate 1998) which carries an increased demand for $\mathrm{P}$. Therefore, $\mathrm{P}$ addition might have supported growth of $\mathrm{N}_{2}$-fixing cyanobacteria by enabling more optimal cellular N/P ratios. Fairchild et al. (1985) showed that $\mathrm{N}_{2}$-fixing periphyton achieved higher biomass after the supply of $\mathrm{P}$, compared with control and $\mathrm{N}$ treatments during an in situ nutrient bioassay investigation in Douglas Lake, Michigan, USA.

Co-limitation was recorded at AT7. The addition of $\mathrm{N}+\mathrm{P}$ supplied together significantly stimulated $\mathrm{Chl} a$ and pigment concentrations indicative of siliceous and green algae by c. $90 \%$, suggesting a severe shortage of both $\mathrm{N}$ and $\mathrm{P}$ for uptake and assimilation. Morris and Lewis (1988) reported that communities composed of a relatively small number of closely related species with similar $\mathrm{N}$ and $\mathrm{P}$ requirements (typical of arctic phytobenthos) commonly 

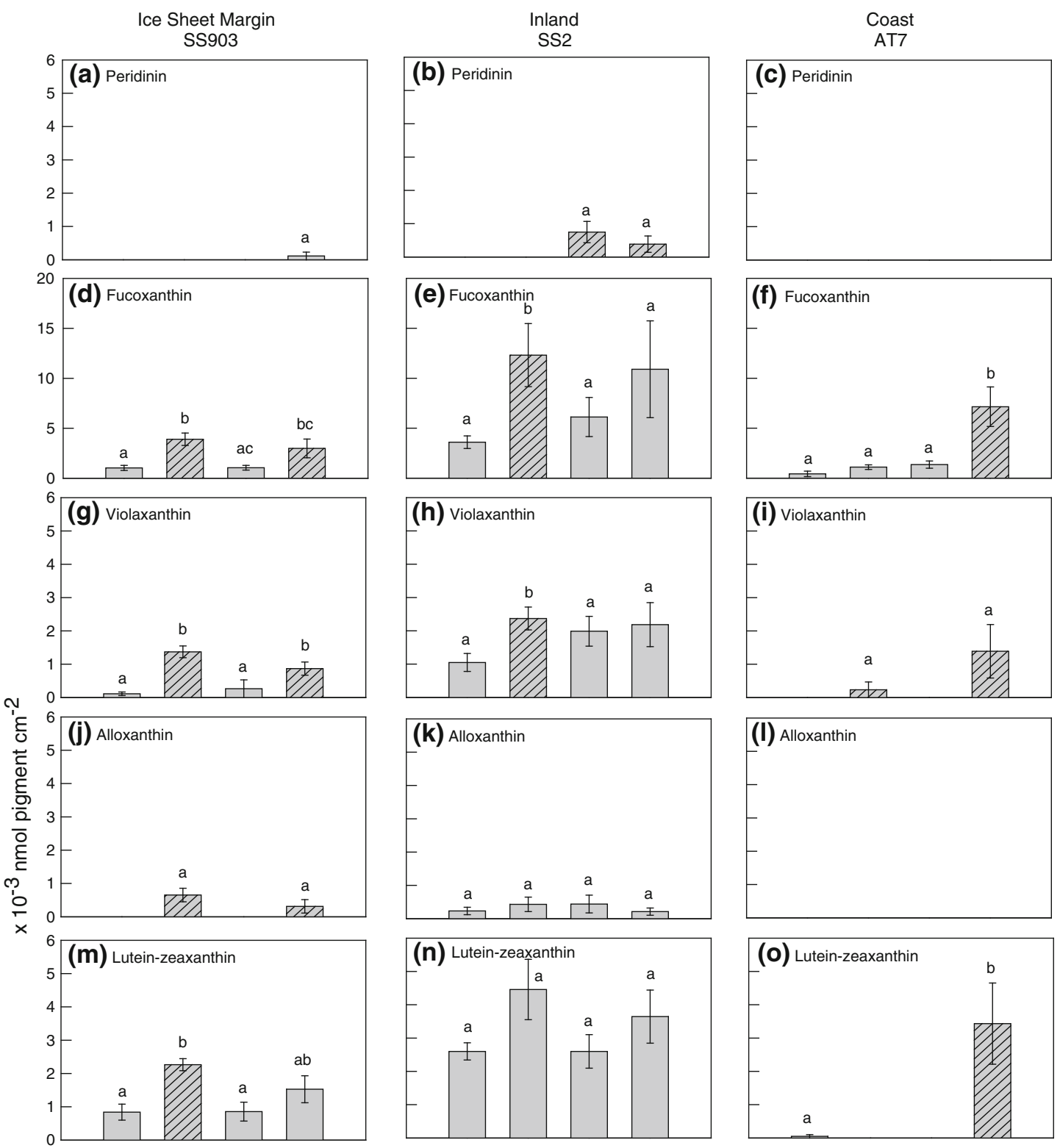

(h) Violaxanthin
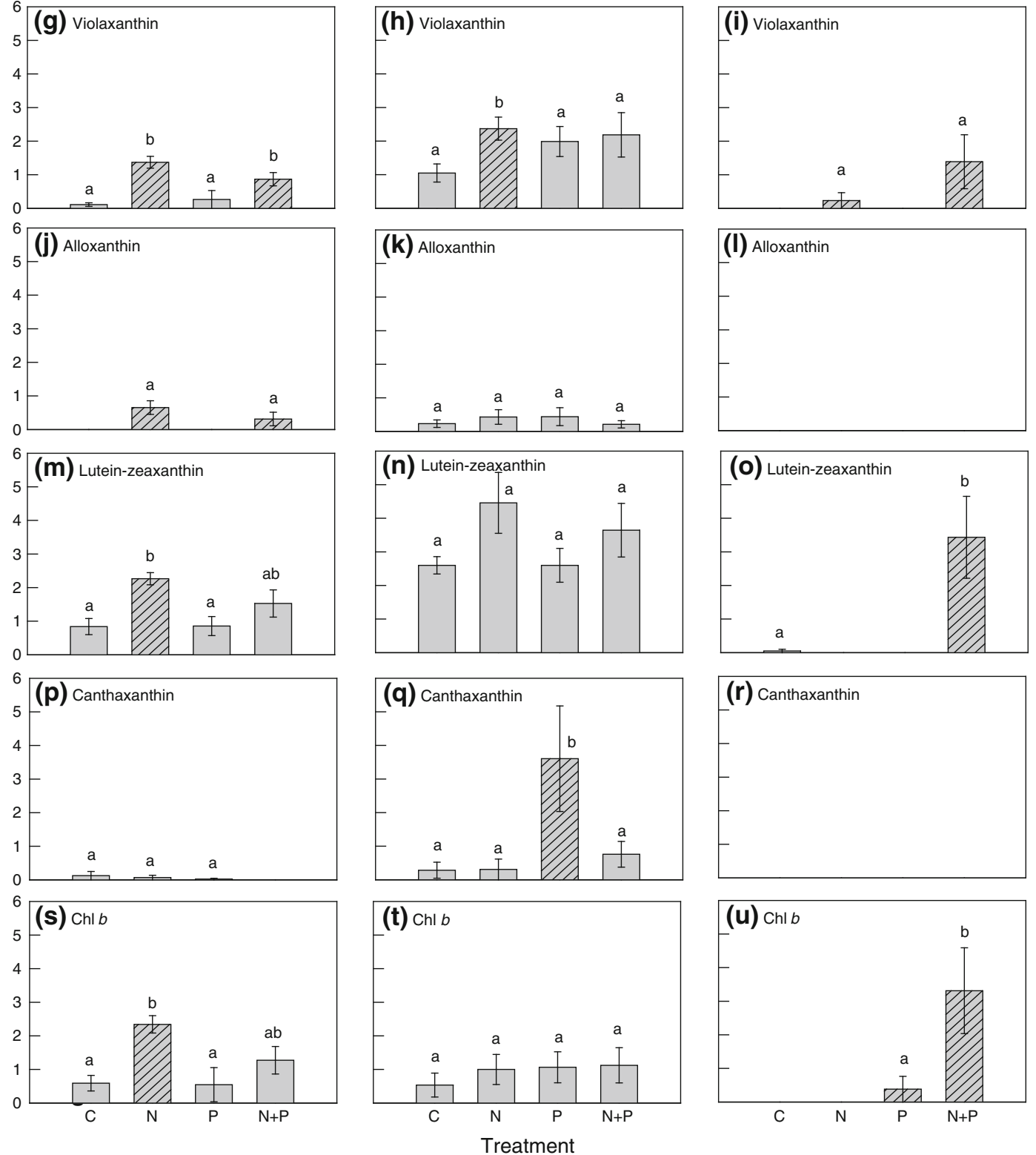
४Fig. 4 Effect of nutrient supply (nitrogen (N), phosphorus (P), $\mathrm{N}+\mathrm{P}$ ) on periphyton photosynthetic pigment concentration compared against control samples (no nutrients) in three study lakes from south-west Greenland: a-c peridinin (dinoflagellates), d-f fucoxanthin (siliceous algae and chrysophytes), $\mathbf{g}-\mathbf{i}$ violaxanthin (chlorophytes), j-l alloxanthin (cryptophytes), m-o lutein-zeaxanthin (chlorophytes), p-r canthaxanthin (cyanobacteria), s-u Chl $b$ (chlorophytes). Plotted values are means $(n=4-6) \pm 1$ SEM, with one-way ANOVA and LSD post hoc test used to calculate significant differences in pigment concentration between nutrient treatments for each lake. Points assigned the same letter are not significantly different at the $P \leq 0.05$ level, with results statistically significant from control samples highlighted by diagonal lines. Note the different $y$-axis scale bar for fucoxanthin $(\mathbf{d}-\mathbf{f})$ compared with other pigment biomarkers

exhibit $\mathrm{N}+\mathrm{P}$ co-limitation. Although $\mathrm{N}+\mathrm{P}$ supply stimulated growth in all three study lakes, co-nutrient limitation was only determined for AT7. Nonetheless, in response to $\mathrm{N}+\mathrm{P}$ supply, maximum $\mathrm{Chl} a$ and pigment values were up to $80 \times$ lower than reported for other study lakes, suggesting potentially lower periphyton biomass and reduced diversity in AT7. The low Chl $a$ and pigment concentrations recorded at AT7 could be explained by heterogeneity in environmental conditions and community composition between lakes (Baulch et al. 2009).

Ice melt is typically delayed at the coast by $c$. 2-3 weeks compared with lakes inland (Anderson and Brodersen 2001). Nutrient diffusing substrata were deployed in lakes within a 3-day period, and although ice melt had occurred $>10$ days earlier at SS2 and SS903, there was still a large volume of ice present on AT7 at the start of the investigation. The growth and natural succession pattern of periphyton in arctic lakes (typified by early spring blooms of siliceous algae and chlorophytes followed by a peak in cyanobacteria later in the growing season) are tightly coupled to ice cover, timing of ice melt and associated limnological changes, in particular, light availability and water temperature. At the start of the investigation, water temperature in the upper $2 \mathrm{~m}$ was $7-10{ }^{\circ} \mathrm{C}$ lower at AT7, potentially resulting in reduced colonisation rates. However, the temperature of water close to the sediment (phytobenthos habitat) in the littoral zone is likely to remain more stable following ice melt and differ less between the three lakes. Hansson (1992) reported similar periphyton Chl $a$ values in Antarctic (2-40 $\mu \mathrm{g} \mathrm{cm}^{-2}$, mean water temperatures $<4{ }^{\circ} \mathrm{C}$ ) and temperate lakes (3-27 $\mu \mathrm{g} \mathrm{cm}^{-2}, c .10-20{ }^{\circ} \mathrm{C}$ warmer), concluding that low water temperature was unlikely to exert a major control over periphyton growth.

Light attenuation through the water column was similar at SS903 and AT7, suggesting variation in PAR availability was unlikely to account for lower Chl $a$ and pigment concentrations at AT7. The lowest PAR (and highest light attenuation) was recorded at SS2, associated with Chl $a$ values $60-80 \%$ higher than other study lakes. This could reflect increased periphyton biomass, but it is important to consider that it could also represent higher individual cellular Chl a concentrations (enhancing light-harvesting capacity) (Lizotte 2008). There is evidence that light (as a result of increased exposure to ultraviolet (UV) radiation) can have a marked effect and reduce periphyton growth and community composition in oligotrophic lakes (Vinebrooke and Leavitt 1996). Although the role of UV radiation was not addressed directly, it could potentially limit Chl $a$ and induce pigment degradation at AT7 which is located at the highest altitude and where there was low light attenuation and associated high PAR.

There was no evidence of cyanobacterial growth (canthaxanthin) on NDS at AT7. This might reflect a lag in the seasonal succession pattern of periphyton, resulting from delayed ice melt. Alternatively, it could represent a lower demand for $\mathrm{N}_{2}$-fixation due to increased $\mathrm{NO}_{3}{ }^{-}$availability. Previous regional studies have reported increased $\mathrm{N}$ availability in lakes at the coast compared with inland (Anderson et al. 2012), which could be attributed to accumulation of atmospheric deposits over winter delivered to lakes during the spring thaw (Rautio et al. 2011).

It was initially hypothesised that regional variation in atmospheric $\mathrm{N}$ deposition (linked to precipitation) might effect the nutrient limitation of lakes across SW Greenland. There is growing evidence that long-range atmospheric transport of $\mathrm{N}$ is now reaching Greenland; preliminary data from a recent regional survey (2010-2012) suggest that $\mathrm{N}$ deposition increases by a factor of 2 from the ice sheet margin to the coast (C. Curtis, Pers. comm). Increased atmospheric $\mathrm{N}$ deposition has previously been shown to shift nutrient limitation of oligotrophic lakes from $\mathrm{N}$ to $\mathrm{P}$ limitation (Bergström et al. 2005; Elser et al. 2009a, b). In agreement with these findings, $\mathrm{N}$ limitation was reported at the lowest $\mathrm{N}$ deposition site (SS903). However, P limitation alone was not reported at the highest $\mathrm{N}$ deposition site (AT7). A shift from $\mathrm{N}$ to $\mathrm{P}$ limitation has previously been reported at rates $>6 \mathrm{~kg} \mathrm{ha}^{-1}$ year ${ }^{-1}$ (Bergström et al. 2005; Elser et al. 2009b), far in excess of atmospheric $\mathrm{N}$ deposition currently estimated for Greenland $\left(<1 \mathrm{~kg} \mathrm{~N} \mathrm{ha}^{-1}\right.$ year $^{-1}$ ) (Arens et al. 2008; C. Curtis, Pers. comm).

South-west Greenland is dominated by small, shallow lakes which typically have high ratios of littoral surface area relative to pelagic volume, typically favouring the growth of benthic phototrophs (Wetzel 1990). Vadeboncoeur et al. (2003) reported that periphyton was responsible for 80-90\% of primary production in similar shallow, oligotrophic lakes in north-east Greenland. However, to date, the majority of studies undertaken on lakes across the study region (including nutrient bioassay studies) have focussed on the phytoplankton community (e.g. Kristiansen 1994; Anderson et al. 1999; Brutemark et al. 
2006). Although information from phytoplankton bioassays can help inform about the nutrient limitation of a lake, one drawback is that the design of such experiments requires 'closed assays' where the algal community is either removed from the lake and grown under controlled conditions (Levine and Whalen 2001; Maberly et al. 2002; Symons et al. 2012), or for in situ experiments, is completely isolated from the surrounding lake water (Brutemark et al. 2006) therefore giving little insight into how algal assemblages adapt to nutrient supply conditions in their natural habitat (Elser et al. 1990).

The use of NDS provides a platform onto which periphyton can attach and grow, whilst exposing algae to the water column continuously throughout the duration of the experiment. As such, it can provide a potentially greater understanding of the nutrient limitation status of the water body and its effect on specific (periphyton) community growth as well as informing more broadly, about the likely nutrient limitation status of other algal groups inhabiting the lake. However, there are limitations to consider when using and interpreting data from NDS, in particular, the ability of artificial substrates to accurately replicate natural substrata (Cattaneo and Amireault 1992). Artificial substrates (including NDS) have been shown to miss-represent natural colonisation rates, periphyton biomass, primary production and species composition (Aloi 1990; Cattaneo and Amireault 1992). This might account for low periphyton Chl $a\left(0.05-2 \times 10^{-2} \mu \mathrm{g} \mathrm{cm}^{-2}\right)$ values recorded in the current study compared with values reported for natural substrates in high-latitude oligotrophic lakes and ponds $\left(0.01-40 \mu \mathrm{g} \mathrm{cm}^{-2}\right.$ ) (Hansson 1992; Vadeboncoeur and Lodge 2000; Bonilla et al. 2005; McMaster and Schindler 2005). Heterogeneity of benthic habitats (deployment of a single experimental set-up) and length of deployment alongside HPLC analysis (rather than trichromatic methodology) and variation in periphyton biomass/pigment ratios (concentrations per cell) (Schagerl and Künzl 2007; Baulch et al. 2009) could also help account for low Chl $a$ values. Nonetheless, results from the current study provide novel information on the nutrient limitation of freshwater lakes in SW Greenland as well as adding to the limited knowledge of periphyton ecology in this region of the arctic. Nutrient limitation of arctic lakes and associated ecological impacts are highly variable, even across small geographic areas. In this highly sensitive region, future environmental change scenarios carry a strong risk of significantly altering nutrient limitation (IPCC 2013), in turn, potentially severely impacting lake structure and function.

Acknowledgments This work was funded by the Natural Environmental Research Council NE/G019622/1. We thank Kent Joensen, Jeff Joensen and Rachel Lem assistance with deploying the experiment, Chris Curtis, James Shilland and Gavin Simpson for collecting samples in the field, and Graham Morris and Teresa Needham for help in the HPLC laboratory. Thank you to Basse Vængtoft and Rikka
Møller at Kangerlussuaq International Science Support (KISS). We thank three anonymous reviewers for their helpful comments on an earlier draft.

Open Access This article is distributed under the terms of the Creative Commons Attribution License which permits any use, distribution, and reproduction in any medium, provided the original author(s) and the source are credited.

\section{References}

Aloi JE (1990) A critical review of recent freshwater periphyton field methods. Can J Fish Aquat Sci 47:656-670

Anderson NJ, Brodersen KP (2001) Determining the date of ice-melt for low Arctic lakes along Søndre Strømfjord, southern West Greenland. Geol Greenland Surv Bull 189:54-58

Anderson NJ, Stedmon CA (2007) The effect of evapoconcentration on dissolved organic carbon concentration and quality in lakes of SW Greenland. Freshw Biol 52:280-289

Anderson NJ, Bennike O, Christoffersen K, Jeppesen E, Markager S, Miller G, Renberg I (1999) Limnological and palaeolimnological studies of lakes in south-western Greenland. Geol Greenland Surv Bull 183:68-74

Anderson NJ, Harriman R, Ryves DB, Patrick ST (2001) Dominant factors controlling the ionic composition of West Greenland lakes. Arctic Antarct Alp Res 33:418-425

Anderson NJ, D'Andrea W, Fritz S (2009) Holocene carbon burial by lakes in SW Greenland. Global Change Biol 15:2590-2598

Anderson NJ, Liversidge L, McGowan S, Jones MD (2012) Lake and catchment response to Holocene environmental change: spatial variability along a climate gradient in southwest Greenland. J Paleolimnol 48:209-222

Anisimov OA, Vaughan DG, Callaghan TV, Furgal C, Marchant H, Prowse TD, Vilhjálmsson H, Walsh JW (2007) Polar regions (Arctic and Antarctic). In: Parry ML, Canziani OF, Palutikof JP, van der Linden PJ, Hanson CE (eds) Climate change 2007: impacts, adaptation and vulnerability. Contribution of working group II to the fourth assessment report of the Intergovernmental Panel on Climate Change. Cambridge University Press, Cambridge, pp 653-685

Arens SJ, Sullivan PF, Welker JM (2008) Nonlinear responses to nitrogen and strong interactions with nitrogen and phosphorus additions drastically alter the structure and function of a high arctic ecosystem. J Geophys Res 113. doi:10.1029/2007/JG000 508

Baulch HM, Turner MA, Findlay DL, Vinebrooke RD, Donahue WF (2009) Benthic algal biomass-measurement and errors. Can J Fish Aquat Sci 66:1989-2001

Bergström A-K, Jansson M (2006) Atmospheric nitrogen deposition has caused nitrogen enrichment and eutrophication of lakes in the northern hemisphere. Global Change Biol 12:635-643

Bergström A-K, Jansson M (2008) Phytoplankton responses to nitrogen and phosphorus enrichment in unproductive Swedish lakes along a gradient of atmospheric nitrogen deposition. Aquat Biol 4:55-64

Bergström A-K, Blomqvist P, Jansson M (2005) Effects of atmospheric nitrogen deposition on nutrient limitation and phytoplankton biomass in unproductive Swedish lakes. Limnol Oceanogr 50:987-994

Bindler R, Renberg I, Anderson NJ, Appleby PG, Emteryd O, Boyle J (2001a) Pb isotope rations of lake sediments in West Greenland: inferences on pollution sources. Atmos Environ 35:4675-4685

Bindler R, Renberg I, Appleby PG, Anderson NJ, Rose NL (2001b) Mercury accumulation rates and spatial patterns in lake 
sediments from West Greenland: a coast to ice margin transect. Environ Sci Technol 35:1736-1741

Blumenshine SC, Vadeboncoeur Y, Lodge DN, Cottingham KL, Knight SE (1997) Benthic-pelagic links: responses of benthos to water-column nutrient enrichment. J N Am Benthol Soc 16: 466-479

Bonilla S, Villeneuve V, Vincent WF (2005) Benthic and planktonic algal communities in a high arctic lake: pigment structure and contrasting responses to nutrient enrichment. J Phycol 41:11201130

Brutemark A, Rengefors K, Anderson NJ (2006) An experimental investigation of phytoplankton nutrient limitation in two contrasting low arctic lakes. Polar Biol 29:487-494

Cattaneo A, Amireault MC (1992) How artificial are artificial substrata for benthic algae? J N Am Benthol Soc 11:244-256

dmi.dk-Danish Meteorological Institute website visited May 2012. Greenland historical climate data for temperature and precipitation for Kangerlussauq and Sisimuit

Elser JJ, Marzolf ER, Goldman CR (1990) Phosphorus and nitrogen limitation of phytoplankton growth in the freshwaters of North America: a review and critique of experimental enrichments. Can J Fish Aquat Sci 47:1468-1477

Elser JJ, Bracken MES, Cleland EE, Gruner DS, Harpole WS, Hillebrand H, Ngai JT, Seabloom EW, Shurin JB, Smith JE (2007) Global analysis of nitrogen and phosphorus limitation of primary producers in freshwater, marine and terrestrial ecosystems. Ecol Lett 10. doi:10.111/j.1461-0248.2007.01113.x

Elser JJ, Andersen T, Baron JS, Bergström A-K, Jansson M, Kyle M, Nydick KR, Steger L, Hessen DO (2009a) Shifts in lake N:P stoichiometry and nutrient limitation driven by atmospheric nitrogen deposition. Science 326:835-837

Elser JJ, Kyle M, Steger L, Nydick KR, Baron JS (2009b) Nutrient availability and phytoplankton nutrient limitation across a gradient of atmospheric nitrogen deposition. Ecology 90: 3062-3073

Fairchild GW, Lowe RL, Richardson WB (1985) Algal periphyton growth on nutrient-diffusing substrates: an in situ bioassay. Ecology 66:465-472

Fairchild GW, Sherman JW, Acker FW (1989) Effects of nutrient (N, $\mathrm{P}, \mathrm{C}$ ) enrichment, grazing and depth upon littoral periphyton of a softwater lake. Hydrobiologia 173:69-83

Hansson L-A (1992) Factors regulating periphytic algal biomass. Limnol Oceanogr 37:322-328

Hastings MG, Jarvis JC, Steig EJ (2009) Anthropogenic impacts on nitrogen isotopes of ice-core nitrate. Science 324:1288

Hodgson DA, Vyverman W, Verleyen E, Saabe K, Leavitt PR, Taton A, Squire AH, Keely BJ (2004) Environmental factors influencing the pigment composition of in situ benthic microbial communities in east Antarctic lakes. Aquat Microb Ecol 37:247-263

Holtgrieve GW, Schindler DE, Hobbs WO, Leavitt PR, Ward EJ, Bunting L, Chen G, Finney BP, Gregory-Eaves I, Holmgren S, Lisac MJ, Lisi PJ, Nydick K, Rogers LA, Saros JE, Selbie DT, Shapley MD, Walsh PB, Wolfe AP (2011) A coherent signature of anthropogenic nitrogen deposition to remote watersheds of the northern hemisphere. Science 334:1545-1548

IPCC (2013) Climate change 2013: the physical science basis. In: Stocker TF, Qin D, Plattner G-K, Tignor M, Allen SK, Boschung J, Nauels A, Xia Y, Bex V, Midgley PM (eds) Contribution of Working Group 1 to the Fifth Assessment Report of the Intergovernmental Panel on Climate Change. Cambridge University Press, Cambridge, UK, 1535 pp

Kristiansen J (1994) Preliminary studies on the distribution of silicascaled chrysophytes in Greenland. Verh Int Verein Limnol 25:2234-2236
Leavitt PR, Hodgson DA (2001) Sedimentary pigments. In: Smol JP, Birks HJB, Last WM (eds) Tracking environmental change using lake sediments. Kluwer, Dordrecht, pp 295-325

Lepori F and Robin J (2014) Nitrogen limitation of the phytobenthos in Alpine lakes: results from nutrient-diffusing substrata. Freshw Biol. doi:10.1111/fwb.12370

Levine MA, Whalen SC (2001) Nutrient limitation of phytoplankton production in Alaskan Arctic foothill lakes. Hydrobiologia 455:189-201

Lizotte MP (2008) Phytoplankton and primary production. In: Vincent FW, Laybourn-Parry J (eds) Polar lakes and rivers: limnology of arctic and Antarctic aquatic ecosystems. Oxford University Press, Oxford, pp 157-178

Lomas MW, Glibert PM (1999) Temperature regulation of nitrate uptake: a novel hypothesis about nitrate uptake and reduction in cool-water diatoms. Limnol Oceanogr 44:556-572

Maberly SC, King L, Dent MM, Jones RI, Gibson CE (2002) Nutrient limitation of phytoplankton and periphyton growth in upland lakes. Freshw Biol 47:2136-2152

Mackereth FJH, Heron J, Talling JF (1989) Water analysis: some revised methods for limnologists, 2nd edn. Titus Wilson, Kendal (Freshwater Biological Association Scientific Publication No. 36)

Matlock MD, Matlock ME, Storm DE, Smolen MD, Henley WJ (1998) Limiting nutrient determination in lotic ecosystems using a quantitative nutrient enrichment periphytometer. JAWRA 34: $1141-1147$

McGowan S, Barker P, Haworth EY, Leavitt PR, Maberly SC, Pates J (2012) Humans and climate as drivers of algal community change in Windermere since 1850. Freshw Biol 57:260-277

McMaster NL, Schindler DW (2005) Planktonic and epipelic algal communities and their relationship to physical and chemical variables in alpine ponds in Banff National Park, Canada. Arctic Antarct Alp Res 37:337-347

Morris DP, Lewis WM (1988) Phytoplankton nutrient limitation in Colorado mountain lakes. Freshw Biol 20:315-327

Nielsen AB (2010) Present conditions in Greenland and the Kangerlussuaq area. Working Report 2010-07, Geological Survey of Denmark and Greenland

Nydick KR, Lafrancois BM, Baron JS, Johnson BM (2004) Nitrogen regulation of algal biomass, productivity, and composition in shallow mountain lakes, Snowy Range, Wyoming, USA. Can J Fish Aquat Sci 61:1256-1268

Poole HH, Atkins WR (1929) Photo-electric measurements of submarine illumination throughout the year. J Mar Biol Assoc $16: 297-394$

Postgate J (1998) Nitrogen fixation, 3rd edn. Cambridge University Press, Cambridge

promice.dk accessed May 2012. Programme for monitoring the Greenland ice sheet. Weather station data

Rautio M, Dufresne F, Laurion I, Bonilla S, Vincent WF, Christoffersen KS (2011) Shallow freshwater ecosystems of the circumpolar Arctic. Ecoscience 18:204-222

Schagerl M, Künzl G (2007) Chlorophyll $a$ extraction from freshwater algae-a reevaluation. Biologia 62:270-275

Smol JP, Wolfe AP, Birks HJ, Douglas MSV, Jones VJ, Korhola A, Pienitz R, Rühland K, Sorvari S, Antoniades D, Brooks SJ, Fallu M-A, Hughes M, Keatley BE, Laing TE, Michelutti N, Nazarova L, Nyman M, Paterson AM, Perren B, Quinlan R, Rautio M, Saulnier-Talbot É, Siitonen S, Solovieva N, Weckström J (2005) Climate-driven regime shifts in the biological communities of arctic lakes. PNAS 102:4397-4402

Sprent JI, Sprent P (1990) Nitrogen fixing organisms. Cambridge University Press, Cambridge 
Symons CC, Arnott SE, Sweetman JN (2012) Nutrient limitation of phytoplankton communities in Subarctic lakes and ponds in Wapusk National Park, Canada. Polar Biol 35:481-489

Tilman D, Kiesling R, Sterner RW, Kilham SS, Johnson FA (1986) Green, bluegreen and diatom algae: taxonomic differences in competitive ability for phosphorus, silicon and nitrogen. Arch Hydrobiol 106:473-485

Vadeboncoeur Y, Lodge DM (2000) Periphyton production on wood and sediment: substratum-specific response to laboratory and whole-lake nutrient manipulations. J N Am Benthol Soc 19:68-81

Vadeboncoeur Y, Lodge DM, Carpenter SR (2001) Whole-lake fertilisation effects on distribution of primary production between benthic and pelagic habitats. Ecology 82:1065-1077

Vadeboncoeur Y, Jeppesen E, Vander Zanden MJ, Schierup H-H, Christoffersen K, Lodge DM (2003) From Greenland to green lakes: cultural eutrophication and the loss of benthic pathways in lakes. Limnol Oceanogr 48:1408-1418

Villeneuve V, Vincent WF, Komárek J (2001) Community structure and microhabitat characteristics of cyanobacterial mats in an extreme high Arctic environment: Ward Hunt Lake. Nova Hedwig 123:199-224

Vincent WF, Hobbie JE, Laybourn-Parry J (2008) Introduction to the limnology of high-latitude lake and river ecosystems. In: Vincent FW, Laybourn-Parry J (eds) Polar lakes and rivers: limnology of arctic and Antarctic aquatic ecosystems. Oxford University Press, Oxford, pp 1-23

Vinebrooke RD, Leavitt PR (1996) Effects of ultraviolet radiation on periphyton in an alpine lake. Limnol Oceanogr 41:1035-1040

Vinebrooke RD, Leavitt PR (1998) Direct and interactive effects of allochthonous dissolved organic matter, inorganic nutrients, and ultraviolet radiation on an alpine littoral food web. Limnol Oceanogr 43:1065-1081

Wetzel RG (1990) Land-water interfaces: metabolic and limnological regulators. Veh Int Ver Theor Angew Limnol 24:6-24

Wolfe AP, Cooke CA, Hobbs WO (2006) Are current rates of atmospheric nitrogen deposition influencing lakes in the Eastern Canadian Arctic? Arctic Antarct Alp Res 38:465-476 